\title{
KNOWLEDGE ECONOMY IN THE SYSTEM OF CONTINUOUS EDUCATION OF UKRAINE
}

\author{
Olena Burunova \\ Sergii Gushko \\ Volodymyr Kulishov \\ Polonia University, Czestochowa, Poland
}

\begin{abstract}
The article investigates the issues and challenges associated with the variability, mobility of technologies of education, development of the conceptual framework based on modernization of economic education, formation of professional knowledge of future specialists of an economic profile in the system of continuous economic education in the conditions of the educational and scientific complex "school-college-university" and the ability economically expedient of such system of knowledge. The economic efficiency of the system of professional knowledge could be achieved through a scientific justification of the project-creative component that is not investigated enough. And there is necessity to implement this experimental innovative component of the professional economic training.

In the process of the research the authors worked out a theoretical cluster system model of knowledge-based economy by applying latest innovative technologies where intersubjective innovative connections are available. The research results involve clarification of the following concepts essence "modernisation of the system of professional knowledge in economics" and "future specialists in the sphere of economics"; introduction of a projectcreative approach in an educational-scientific complex "a school with its economic specialization - a college of economics - a university of economics" under conditions of continuous economic education.
\end{abstract}

Keywords: education, knowledge, economic, system, specialist.

\section{Introduction}

Mankind entered an innovative type of social progress in the period of intense development when changes in ideas, technologies and knowledge occur quicker than one generation alternates another one. The challenges connected with variability and mobility of technologies contribute to the transformation of a modern economic structure of the Ukrainian society, the knowledge society in the post-industrial economy, into knowledge-based economy. In a new information society a competitive system of economic knowledge should be a priority. The formation of which is provided by the training of competent specialists in the sphere of economics.

Modernization of educational activity, which began in our country 
according to the national doctrine based on the personal oriented education completely conforms to requirements of the modern accelerated social development. At the same time there is also a necessity of forming of an extensive system of training during the life for future specialists in the sphere of economics through the extreme dynamism and variability of modern global and national financial-economic and industrial-innovative space that particularly nowadays refreshes the conceptual and theoretical analysis of the issues related to the peculiarities and problems of implementation of economic education throughout life.

Now there is a problem of development of the conceptual framework based on improving of the economic efficiency of Ukrainian education to the European educational standards, where the important place is taken by urgent issues connected with the formation of the system of future specialists' professional knowledge in the economical sphere. In the process of formation of this system it's essential to take into account the principle of continuity. Besides it presupposes the structuring of thematic units of theoretical and real economy and effective interaction of subsystems of specialized, secondary and higher professional economic education. Whereupon the priority is the project creative approach to the stage - by - stage formation of knowledge economy in the system of continuous economic education under conditions of the educational and scientific complex "school-college-university" (Kulishov, 2011).

In the modern educational process at the institutions of economic education it is necessary to ensure pupils and students to get new knowledge and new information, develop the need of self-knowledge and cultural and economic selfrealization of personal power potential. Homo sapiens in the XXI century is a person, who studies all life and has the identity of "economic type". Economic personality type of the information society is characterized not only by his/her ability to economically effective introduction of the system of professional knowledge, but also by the ability economically expedient of such system of knowledge. Economically viable system of professional training is the mutually supplementing set of information resources, in which pupils and students become proficient with a minimum of effort. The efficiency of the system of professional knowledge could be achieved through a scientific justification of the project - creative component in such system. Only a modern specialist in the economical sphere whose project-creative competence is shaped will be able to subjectively provide the process of innovative development of the information society which is objectively caused under conditions of globalization processes.

Search of regularities for systematization of the purposes in the pedagogical process always drew attention of teachers. One of the first pedagogical taxonomies is "Taxonomy of Educational Objectives," which was 
developed by the American scientist B. Bloom and his followers. Objectives define the general orientation of the whole system of future specialists' preparation in the economical sphere.

The ideas of American scientists J. Carroll (Carroll, 1963) and B. Bloom (Bloom, 1964) became psychological basis of the mastery learning system. Depending on the intellectual abilities of different students it takes different time to master the same learning material. However, traditionally organized educational process ignores this reality and demands from all pupils to learn all material to the term which is the same for everyone.

It is important to develop psycho-pedagogical conditions for complete assimilation of the required teaching material by every student willing and able to learn. The philosophical basis of this system was the idea of student-centered education by the American philosopher J. Dewey (Dewey, 1940). Priority value was gained by self - education and self-control, and also development of the technological training tools which help to such organization during educational process.

Methodologic and scientific approaches, which belong to the problem solution related to the formation of the system of future specialists' professional knowledge in the economical sphere did not single out a project-creative approach into the formation of the system of future specialists' (who potentially are senior pupils of secondary schools) professional knowledge in the economical sphere, did not pay sufficient attention to the continuity principle of the pre-professional knowledge system formation in economics in the specialized schools and professional knowledge in economical colleges. It means they did not set themselves the aim to research theoretical and methodological approaches to the professional knowledge formation in the system of future specialists' continuous education in the economical sphere.

According to the aforesaid, it is necessary to recognize that the project creative approach to the formation of the system of future specialists' professional knowledge in the economical sphere remains insufficiently investigated. It becomes more and more apparent that the professional economic training of specialists lacks for an investigative and innovative component which would take into account the requirement of every student's natural abilities development: educational, cultural, project and project - creative. Only a creatively developed specialist can be an economically effective personality at the modern labour market. Modern labour market, its development and dynamics of its changes require educational institutions to train professionals with innovative knowledge and skills who are fluent in the theoretical bases of economic knowledge, understand all aspects of application in practical activities of innovative technologies, have the skills to update and improve knowledge throughout life. So, there is a need of further improvement of scientific 
justification and introduction of innovations, modernizations of the educational sector in general and economic education in particular.

There are important pre-requisites for further research of development of national economic education, improvement of education quality in management and economics, perfection of modular and rating technology of economical and pedagogical disciplines study in the process of system formation of higher educational institution students' professional knowledge. To implement all these we should more actively involve foreign teachers and scientists who have dealt with a tried-and-tested school of selection and teaching of economic disciplines, carry out the adaptation of their learning programmers, extend the practice of training and retraining of research and educational personnel at relevant universities of foreign countries for the system of national economic education, determining the development of domestic economy, which has achieved the level of market principles of functioning.

That is, that the Ukrainian education system has some problems that need to be overcome. The important point in this aspect is improvement of a paradigm of further development of continuous economic education, increase of its quality and a role in development of innovative economy. Finding ways of achievement of it is also the purpose of our study.

\section{The cluster system paradigm of knowledge economy}

Development of economic education is predetermined by a new era of "knowledge economy". Therefore, during the era of new social and educational values the problem of formation of "an economic person", and also such key concepts, as didactic principle of economic efficiency of education; key economic competence; economic ability and economic endowments have become essential (Kulishov, 2011).

Modern domestic education needs radical reorganization of the system of continuous economic education taking into account the competence-based and personally focused approaches. And here prerogative belongs to specialized schools, colleges and universities, the task of which is to give future experts on economics personally - valuable and sensitive-expedient knowledge in economic theory, namely, in microeconomics, business, financial system, management and marketing of intellectual property, information, professional knowledge of national and world economy and global processes of market economy.

The authors studied the works devoted to theoretical bases of senior pupils' training with specialization in economics at secondary school. It was revealed that there is not enough attention to competence-based and personal focused approaches to the profile economic training. At interschool industrial training 
centres the experience of work with economically gifted senior pupils of secondary schools was not revealed either.

Pedagogical and psychological diagnostics of economically gifted senior pupils, its contents and structural features, scientific justification and formulation of the essence appeared to be beyond the attention of national researchers in the sphere of psychology and pedagogics regardless of the requirements of personal- and competence-based doctrine of the Ukrainian education, government programmes concerning identification and pedagogical support of gifted youth and standards of basic and secondary education.

Researches of a professional knowledge formation problem in higher economic educational institutions are especially versatile. In the course of modern theoretical sources analysis in economy, based on the principles of person-centric approach the divergence between scientific provisions in education philosophy, requirements of personal- and competence-focused doctrine of the Ukrainian education and a real state of professional knowledge formation in continuous system of economic education is revealed. So, the essence of competence consists in professional possession of not only knowledge, skills and experience, but also in positive expert's attitude to their requirement and use (Padalka, 2012). In other words, a competence-focused approach is inseparably connected with a personally oriented one, and consequently with the ability of pupils and students for self-education at all the levels: specialized, secondary and higher. Mainly economically gifted pupils and students are clever at self-education, self-development and cultural selfrealization, at study in the continuous system of economic education and training throughout life.

Economically gifted specialist is a competent expert who is clever at mastering of professional knowledge in economics spending minimum of effort and acquiring maximum of academic achievements in the process of continuous economic education. Economically gifted pupils of specialized schools, colleges and economic students of higher economic schools are notable for wellformedness of entrepreneurial competence foreseen by new standards of education. The requirement of the standards is expanding the boundaries of knowledge regarding innovation and global change. Based on this methodology of educational regulatory document it becomes possible to modernize the system formation of professional knowledge of future specialists in the economical sphere who show natural economic endowments and need support for their further development in pedagogically appropriate learning environment. Such pedagogically appropriate learning environment can be educational-scientific complex of an economic profile "school-college-university", which is popular in European countries. 
Market economy introduces new conditions of the educational process organization in educational institutions concerning the formation of high professional knowledge of future specialists in the economical sphere. In Ukraine reproductive method of teaching does not meet the present. Society needs professionals with creative thinking, the ability to navigate in an increasingly competitive market. The secondary school provides the foundation for economic education and development of creative abilities. Except general comprehensive knowledge it is urged to carry out economic education of senior pupils, to carry out a number of corresponding functions in the process of study, which induce a personality to the choice of profession and orientation in a working career in conditions of market system. Foundations of elementary economics, business, construction and functioning of market infrastructure make up a sensitively rational logical component of secondary school seniors' professional knowledge.

Taking into account the existence of a competence-based approach in Ukrainian education it is important that senior pupils of a specialized school attain adequate understanding of the concept "enterprise competence", which in state standards is considered to be among key ones. So it constitutes the totality of knowledge, skills and experience about organizationally separated and economically independent sector of management (economy), which makes production or provides paid services, strengthened by emotionally positive attitude and aspiration to creation and realization of economically expedient master - plans, business plans, strategic and marketing plans.

To acquaint senior pupils with a financial system of market economy a project and technological approach appeared to be effective. It allowed pupils to implement knowledge, abilities and personal experience in educational exploratory activity. Its essence consisted in the development of various financial projects (business plans) by pupils of specialized school. The spheres of the activity these projects concerned are following: person-nature, personmachinery, person-person, person-artistic images, person-sign systems. Projecting is provided in substantial filling of the standard of educational branch of "Technology", in the specialized programme on the basis of economics approved by The Ministry of Education and Science of Ukraine. Pupils have an opportunity to choose personally significant environment for the development of an educational master-plan, business-plan, etc.

Capital as a factor of school production (productive labour of seniors) creates the income, which is the reward for the student-entrepreneur. During the projecting process, seniors should realize that the value of contingent capital is a percentage, i.e. the income on primary capital invested in production. Finally seniors of specialized school have to consider the market as a certain set of the economic relations between various types of the enterprises and individuals 
concerning purchase and sale of goods and services where is a final recognition of their cost and realization, adequately aware of essence of the competition among producers for the reduction the expenses of production and increase of public usefulness of goods.

Special attention in the content of training of economic colleges needs to be paid to knowledge about immaterial forms of national wealth: the saved-up experience of people, their abilities, requirement, creative talents, and cultural values. The role of this component in the conditions of market economy increases extremely. Pupils are brought to the conclusion about necessity of the development of their own ability to many-sided and cultural self-realization in the society. Yet in a knowledge society a creative (scientific, art, technical) potential of an employee gets powerful economic value as it governs business projects and technological breaks in economy. Therefore, such qualities of the personality as independence and enterprise act are in the forefront.

Taking into account the financial and economic crisis in the world, professional knowledge of college students about the directions of anti-crisis policy in the economic security of the enterprise activity and methods of restructuring, reorganization and bankruptcy are relevant and well-timed.

Market relations complicate the business environment significantly and enhance the competition between economic entities that can worsen their economic situation and, consequently, lead to bankruptcy. Therefore, in market conditions the formation of the knowledge systems to ensure national economic security of national businesses is always an important task.

Notwithstanding the obvious achievements of Ukrainian economic education, there is a number of questions concerning the essence of theoretical and methodical bases of the system formation of future specialists' professional knowledge in the economical sphere in the conditions of market economy, which are still investigated insufficiently. It is necessary that students comprehend nature and mechanisms of economic laws nowadays, changes in global economic environment and fierce competition from economical and pedagogical position. So to provide sustainable development of a national economic system based on the latest pedagogical technologies it is important that graduates of higher educational economic establishments receive highly professional knowledge.

In this aspect, in a practical way forming the professional knowledge in the process of continuous economic education in the international educational and scientific cooperation in the programme "Double diploma" Master's Degree in "International Economic and Legal Relations" Kryvyi Rih economic Institute (Ukraine) in cooperation with Polonia University in Czestochowa (Poland) train specialists in the field of the theory and practice of international relations with in-depth study of issues of public international law, acquire the necessary 
knowledge to conduct economic activity in the conditions of functioning of the common market of the European (Kryński, Kuliszow, Guszko, 2015).

In the context of relevance of this problem innovative development and creativity of youth in the process of economic education is important. Developing economic system has wide infrastructure of the human relations. Instability and the preponderance of labour supply over demand can be noticed in some spheres of activity. It places emphasis on the preparation of creative young people, able to work under conditions of competitive market environment. To all that one should add the preparation of especially creative youth, that will serve as the foundation of national elite in the future.

Conducted researches give a reason to believe that a new paradigm for the development of education in general and economic, in particular, provides the transition from factual learning model to a methodology of "teaching to learn", actualizes the problem of economic education of the young generation, the enrichment of professional knowledge that are necessary in the current globalized economy and education.

The primary and urgent task of educational institutions for the formation of graduates' professional knowledge system is the creation of a constructive variant of studying the disciplines which meet the requirements of the time and first of all, of market economy in the context of which the role of such social values as knowledge, competence, professionalism, the ability to create something new and progressive which ultimately forms the personality, ready for various types of economic activity become important.

Furthermore, qualitative and quantitative parameters of pedagogical educational processes in the system of continuous education, their intensity and productivity depend first of all on the education of the society or on the power of innovative capacity of the society in the course of economic specialists training. Innovative potential of the society is the level of education, of the knowledge, which is gained by the youth in the course of training and in the process of a specialist forming, possessing a high level of professional knowledge in economics, international global problems, information technologies, foreign languages, intellectual property, and high culture of business communication for working activity in competitive market economy.

In the course of our research we used the latest innovative technologies to develop a theoretical model of a cluster system of knowledge economy. The intersubjective innovative connections in this system serve as a special component that substantially determines the speed of knowledge transformation into technologies and their diffusion in economy (fig. 1). 


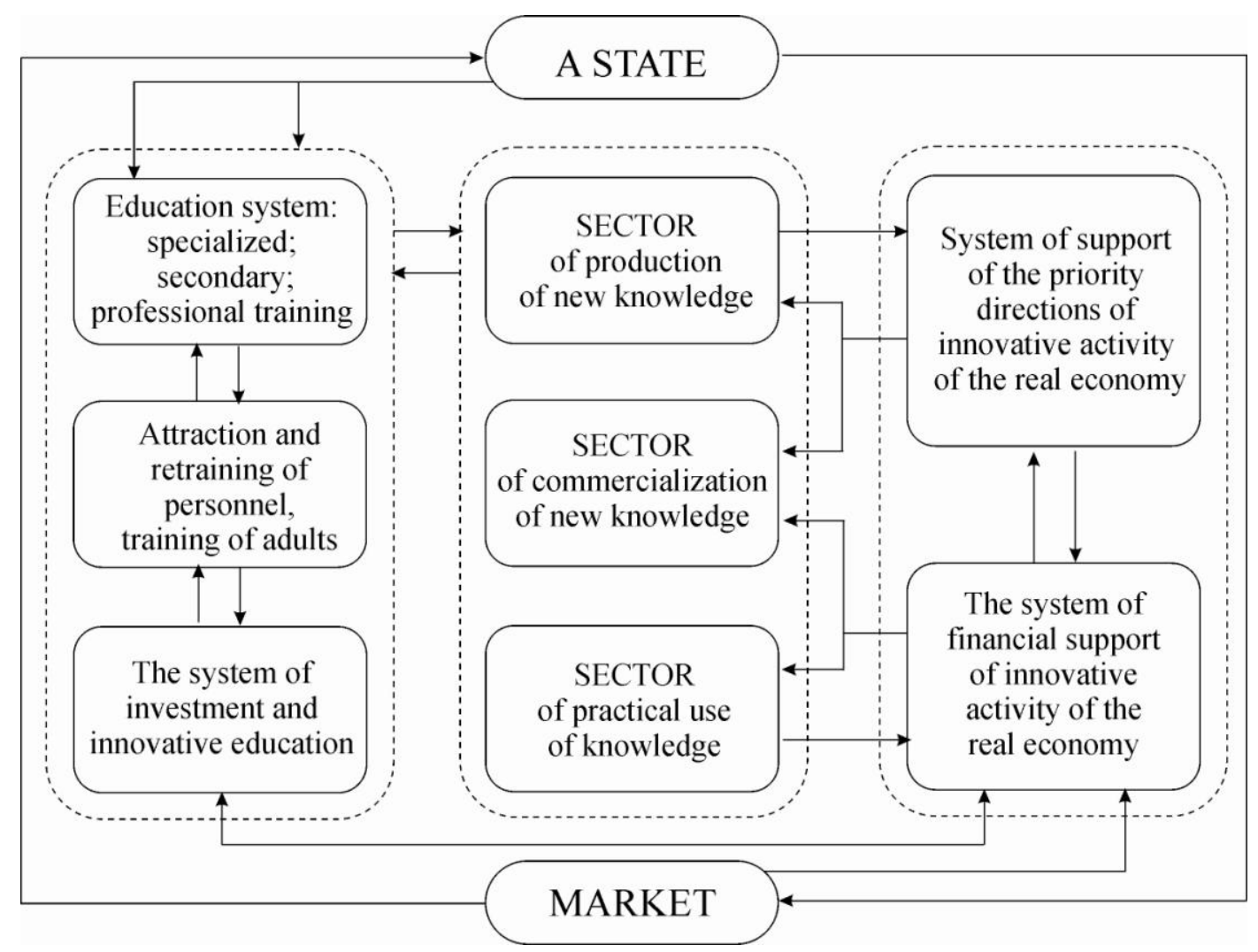

Fig. 1 Theoretical model of cluster system of the knowledge economy (Source: Pedalka O., Kulishov V., 2015)

Fig.1 shows that interconnected components of the knowledge economy are the system of continuous education and its investment and innovation support; the sectors of production, commercialization and practical use of new knowledge; an efficient innovation system of the real economy, which unites and provides information to all market subjects at the state level.

Theoretical model of cluster system of the knowledge economy suggests that "exit" for a secondary school is a higher school, for which, in turn, "exit" is domestic economy, i.e. the enterprise, organization and structure of various types that need specialists with higher education. In other words, the economy should affect the higher education system through requirements on the quality of education and necassary fields of study and etc (Padalka, Kuliszow, 2012).

Having considered issues concerning modern development of the effective system formation of continuous economic education throughout life, transition of national economy based on new knowledge formation, use of the developed countries experience in preparation and retraining of personnel for the system of economic education, and also positive opportunities of economic education innovative potential, we can draw a number of interconnected conclusions. 
Olena Burunova, Sergii Gushko, Volodymyr Kulishov. Knowledge Economy in the System of Continuous Education of Ukraine

\section{Conclusions and suggestions}

Firstly, it is necessary to clarify the concepts "modernization of the system of professional knowledge in economics" and "future specialists in the economical sphere". In our opinion, modernization of the system of professional knowledge in economics consists in the improvement of the training content of specialized school students' professional knowledge in "Elementary Economics", economic college junior specialists' professional knowledge in the production activity of enterprises, higher economic educational institution students' professional knowledge in international economic relations in the world economy. The result of this process is a hierarchical system of professional knowledge in Economics, which step by step becomes understandable for pupils and students in supportive pedagogical conditions of an educational and scientific complex: specialized school-college-university.

Future specialists of an economic profile are seniors of a secondary school who have the key competence of entrepreneurship as a priority; junior specialists of economic colleges are characterized by the project-creative approach to the formation of professional knowledge on economy, knowledge of students of the higher economic educational institutions is found in the creativity and searches of innovative professional knowledge in economics.

Secondly, the authors propose ways to modernize specialized study of Economics at the secondary school. Among these ways there is a pedagogically appropriate methodical system, the priority components of which are projectcreative methods of pre-professional knowledge mastering in Economics and the formation of key competence of senior pupils' entrepreneurial activities.

It should be noted that Ukraine has already made significant steps towards the introduction of specialized economic education at secondary schools, establishing the fundamental basis for the development of an integral system of continuous economic education, which is at a stage of the difficult but consecutive statement. It is shown in the activity of economic lyceums, gymnasiums, colleges, economic classes at secondary schools, and also at universities and postgraduate education for teachers of technology and teachers of economic subjects who are attracted by specialized school. Today a significant amount of textbooks and manuals are printed. They take into account new standard requirements of personal and competence-based basic and secondary education, which are directed at the formation of future graduates' high level of pre-professional knowledge in the field of Economics. Therefore the pedagogical system of pre-professional economic education of specialized school pupils is the main source of the innovative model of economy development. 
Thirdly, there is an urgent necessity of the theoretical and methodological foundations improvement of college junior specialists' personal- and competence-based professional economic education. In the economy based on knowledge, the main resource of development is the innovative potential of a country, which was involved in the regional labour market, small and medium businesses. Therefore the pedagogical system of professional economic education of junior specialists is the main source of innovation model of economic development taking into account its regional features.

The significant theoretical basis of college junior specialists' professional economic education is the production activity scorecard content of the enterprises of regional subordination, while the effective methodological basis of the professional knowledge formation of future junior specialists in the economical sphere is the use of active cooperation forms between students and teachers and interactive cooperation forms between students and students, and pedagogically motivated actualization of Economics studying and teaching methods. Fourthly, it is necessary to effectuate innovative theory and methodology of higher educational institution future specialists' professional knowledge formation in order to protect the economic sovereignty of Ukraine, the main components of which is the development of productive forces, investment and innovation relations, economic property and economic mechanism. It is important to improve pedagogical conditions favourable for the graduate students who have to become professionals with high creative, intellectual and organizational capacity, which prevents the decrease in intelligence of the nation, contributes to strengthening human capacity in the domestic economy.

All this, under our deep conviction, will accelerate the development of innovative educational policy, and build the economy of knowledge in the system of continuous education in the context of the Ukrainian entry into the European educational and research collaboration.

\section{References}

Azzam, Amy M. (2009). Why Creativity Now? A Conversation with Sir Ken Robinson. Teaching for the 21st Century, September, vol. 67, no. 1, 22-26, retrieved 26 January 2015, http://www.ascd.org/publications/educational-leadership/sept09/vol67/num01/ Why-Creativity-Now\%C2\%A2-A-Conversation-with-Sir-Ken-Robinson.aspx.

Bloom, B.S., Masia, B.B., Krathwohl, D.R. (1964). Taxonomy of Educational Objectives. Volume II: The Affective Domain. N.Y.: McKay.

Carrol, J. B. (1963). A model of school learning. Teachers College Record. May, 723-730.

Dewey, J. (1940). My Pedagogic Creed Education Today. Edited and with a Foreword by Joseph Rather. C.P. Putnam's Sons. - New York. P. 3-17. 
Olena Burunova, Sergii Gushko, Volodymyr Kulishov. Knowledge Economy in the System of Continuous Education of Ukraine

Goodyear, P. (2005). Educational design and networked learning: Patterns, pattern languages and design practice. Australasian Journal of Educational Technology, 21(1), 82-101.

Kryński, A., Kuliszow, W., Guszko, S. (2015). Program «Podwójny dyplom: wspótczesne realia». Globalne aspekty Gospodarstwa Światowego i Stosunków Międzynarodowych w warunkach niestabilności gospodarki: materiały Międzynarodowej NaukowoPraktycznej Konferencji Studenckiej, Częstochowa, Akademia Polonijna.

Mishkin, F. S. (1999). Learning from the market: Integrating The Stock Game across the Curriculum. New York: National Council on Economic Education.

Padalka, O., Kulishov, V. (2015). National and European education: achievements and acquision. European pedagogical studies / Association of Rectors of Pedagogical Universities in Europe; ed. board V. Andrushchenko (head) [and others]. - Issue 5-6. K.: Publishing house of the National Pedagogical Dragomanov University.

Yankelovich, A. (1996). National Survey of Economic Education. N.-Y.: Philips Petroleum Co.

Кулішов, В. (2011). Методичні засади формування економічної компетентності у проиесі підготовки фахівиів технологій. [Монографія]. К.: Каравела.

Падалка, О. (2012). Економіка освіти та управління: [навчальний посібник]. К.: Педагогічна думка. 